\title{
L-type voltage-gated calcium channels in conditioned fear: A genetic and pharmacological analysis
}

\author{
Brandon C. McKinney, ${ }^{1,2}$ Wilson Sze, ${ }^{3}$ Jessica A. White, ${ }^{3}$ \\ and Geoffrey G. Murphy $2,3,4,5$

\begin{abstract}
${ }^{1}$ Medical Scientist Training Program, University of Michigan, Ann Arbor, Michigan 48109, USA; ${ }^{2}$ Neuroscience Program, University of Michigan, Ann Arbor, Michigan 48109, USA; ${ }^{3}$ Molecular \& Behavioral Neuroscience Institute, University of Michigan, Ann Arbor, Michigan 48109, USA; ${ }^{4}$ Department of Molecular \& Integrative Physiology, University of Michigan, Ann Arbor, Michigan 48109, USA
\end{abstract}

\begin{abstract}
Using pharmacological approaches, others have suggested that L-type voltage-gated calcium channels (L-VGCCs) mediate both consolidation and extinction of conditioned fear. In the absence of L-VGCC isoform-specific antagonists, we have begun to investigate the subtype-specific role of LVGCCs in consolidation and extinction of conditioned fear using a molecular genetics approach. Previously, we used this approach to demonstrate that the $\mathrm{Ca}_{\mathrm{v}} 1.3$ isoform mediates consolidation, but not extinction, of contextually conditioned fear. Here, we used mice in which the gene for the L-VGCC pore-forming subunit $\mathrm{Ca}_{\mathrm{v}} 1.2$ was conditionally deleted in forebrain excitatory neurons $\left(\mathrm{Ca}_{\mathrm{v}} 1.2^{\mathrm{cKO}}\right.$ mice) to address the role of $\mathrm{Ca}_{\mathrm{v}} 1.2$ in consolidation and extinction of conditioned fear. We demonstrate that $\mathrm{Ca}_{\mathrm{v}} 1.2^{\mathrm{KOO}}$ mice consolidate and extinguish conditioned fear as well as control littermates. These data suggest that $\mathrm{Ca}_{\mathrm{v}} 1.2$ is not critical for these processes and together with our previous data argue against a role for either of the brain-expressed L-VGCCs $\left(\mathrm{Ca}_{\mathrm{v}} 1.2\right.$ or $\left.\mathrm{Ca}_{\mathrm{v}} 1.3\right)$ in extinction of conditioned fear. Additionally, we present data demonstrating that the L-VGCC antagonist nifedipine, which has been used in previous conditioned fear extinction studies, impairs locomotion, and induces an aversive state. We further demonstrate that this aversive state can enter into associations with conditioned stimuli that are present at the time that it is experienced, suggesting that previous studies using nifedipine were likely confounded by drug toxicity. Taken together, our genetic and pharmacological data argue against a role for $\mathrm{Ca}_{\mathrm{v}} 1.2$ in consolidation of conditioned fear as well as a role for L-VGCCs in extinction of conditioned fear.
\end{abstract}

Pavlovian fear conditioning is a popular paradigm for both the study of associative learning (Fanselow and Poulos 2005) and modeling anxiety disorders (Delgado et al. 2006; Hofmann 2007). In this paradigm, an association between a conditional stimulus (CS) and an aversive unconditional stimulus (US) is acquired through pairing the CS with the US. Learning of this association is identified by the emergence of new responses to the $\mathrm{CS}$, termed conditioned fear responses. The process by which this learning is transformed into a stable long-term memory with the passage of time is referred to as consolidation. A fear response is said to be contextually conditioned when it is elicited by the context in which the US was delivered. In this case, the context is the CS. Once the CS-US association is established, responding to the CS can be diminished by repeatedly presenting the CS in the absence of the US-this process is referred to as extinction. In the case of contextually conditioned fear responses, extinction can be accomplished through extended exposure to the conditioning context in the absence of the US.

Previous work has suggested that L-type voltage-gated calcium channels (L-VGCCs) mediate both consolidation (Bauer et al. 2002) and extinction (Cain et al. 2002, 2005; Suzuki et al. 2004) of Pavlovian conditioned fear. All of these studies have used pharmacological antagonists to demonstrate a role for LVGCCs (Bauer et al. 2002; Cain et al. 2002, 2005; Suzuki et al.

\footnotetext{
${ }^{5}$ Corresponding author.
}

E-mail murphyg@umich.edu; fax (734) 936-2690.

Article is online at http://www.learnmem.org/cgi/doi/10.1101//m.893808.
2004). One limitation of these studies is that the L-VGCC antagonists used target all L-VGCCS and do not allow for the identification of the specific brain-expressed L-VGCC, $\mathrm{Ca}_{\mathrm{v}} 1.2$ or $\mathrm{Ca}_{\mathrm{v}} 1.3$, involved. Therefore, to investigate the subtype specific role of LVGCCs in consolidation and extinction of conditioned fear, we have adopted a molecular-genetics approach. Previously, we used this approach to demonstrate that deletion of the $\mathrm{Ca}_{\mathrm{v}} 1.3$ subtype disrupted consolidation, but not extinction, of contextually conditioned fear (McKinney and Murphy 2006).

In the present study, the role of $\mathrm{Ca}_{\mathrm{v}} 1.2$ in consolidation and extinction of conditioned fear was examined using mice in which the gene for the L-VGCC pore-forming subunit $\mathrm{Ca}_{\mathrm{v}} 1.2$ was conditionally deleted in the fore-brain $\left(\mathrm{Ca}_{\mathrm{v}} 1.2^{\mathrm{cKO}}\right.$ mice). We have previously demonstrated that these mice have disrupted remote spatial memories (White et al. 2008). Here we demonstrate that conditional deletion of $\mathrm{Ca}_{\mathrm{v}} 1.2$ does not disrupt consolidation of conditioned fear. In addition, we find that deletion of $\mathrm{Ca}_{\mathrm{v}} 1.2$ does not significantly impact the extinction of conditioned fear. Taken together with our previous finding that $\mathrm{Ca}_{\mathrm{v}} 1.3$ was not required for extinction, these results suggest that LVGCCs do not play a significant role in extinction of conditioned fear. Because these results were at odds with previous findings (Cain et al. 2002, 2005; Suzuki et al. 2004), we replicated the studies that implicated L-VGCCs in extinction of conditioned fear by blocking extinction of conditioned fear with systemic administration of the L-VGCC antagonist nifedipine. However, we find that the apparent extinction impairment in mice treated with nifedipine is likely the result of nifedipine's ability to decrease locomotion and induce an aversive state in mice. 


\section{Results}

\section{Conditional deletion of $\mathrm{Ca}_{\mathrm{v}} \mathrm{1.2}$ in the basolateral amygdaloid complex of $\mathrm{Ca}_{\mathrm{v}} 1.2^{\mathrm{cKO}}$ mice}

Conditional deletion of $\mathrm{Ca}_{\mathrm{v}} 1.2$ was achieved by crossing mice in which exon 2 of $\mathrm{Ca}_{\mathrm{v}} 1.2$ was flanked by two loxP sites with mice in which expression of cre-recombinase is driven by the calciumcalmodulin-dependent kinase II $\alpha$ (CaMKII $\alpha$ ) promoter (termed CaMK-Cre here) (Chen et al. 2006). The conditional deletion of $\mathrm{Ca}_{\mathrm{v}} 1.2$ in the neocortex and hippocampus of $\mathrm{Ca}_{\mathrm{v}} 1.2^{\mathrm{cKO}}$ mice, two brain regions critically involved in fear conditioning and its extinction (Maren 2001; Myers and Davis 2006), has previously been described (White et al. 2008). We have subsequently conducted a series of experiments to examine the expression pattern of cre-recombinase and to determine the extent of the deletion of $\mathrm{Ca}_{\mathrm{v}} 1.2$ in the basolateral amygdaloid complex (BLA; composed of the lateral, basolateral, and basomedial amygdaloid nuclei).

To assess the pattern of cre-recombinase expression pattern, we crossed hemizygous CaMK-Cre mice with homozygous R26R reporter mice, which carry the loxP-STOP-loxP-lacZ cassette targeted into the ubiquitously expressed ROSA26 locus (Soriano 1999). Brains from bigenic animals were stained for $\beta$ galactosidase activity. $\beta$-Galactosidase activity, and thus crerecombinase expression, was present in much of the forebrain of these mice (Fig. 1A), including the BLA (Fig. 1A, inset). To determine the extent of $\mathrm{Ca}_{\mathrm{v}} 1.2$ deletion within the BLA, we subjected tissue punches from the BLA of $\mathrm{Ca}_{\mathrm{v}} 1.2^{\mathrm{cKO}}$ mice to Western blot analysis using anti-Ca $\mathrm{a}_{\mathrm{v}} 1.2$-specific antibodies. Figure $1 \mathrm{~B}$ shows a representative section of mouse brain from which a BLA tissue punch was obtained. Western blot analysis of brain tissue isolated from BLA tissue punches is presented in Figure 1C. Consistent with our previous findings in the hippocampus and cortex (White et al. 2008), deletion of exon 2 of $\mathrm{Ca}_{\mathrm{v}} 1.2$ resulted in complete loss of immunoreactivity within the BLA.

\section{Conditional deletion of $\mathrm{Ca}_{\mathrm{v}} 1.2$ does not disrupt consolidation of contextual conditioned fear memories} As described above, others have implicated L-VGCCs in consolidation of conditioned fear (Bauer et al. 2002), and we have previously demonstrated that $\mathrm{Ca}_{\mathrm{v}} 1.3$ mediates consolidation of contextually conditioned fear (McKinney and Murphy 2006). To determine if $\mathrm{Ca}_{\mathrm{v}} 1.2$ might also contribute to consolidation of contextually conditioned fear, we conditioned $\mathrm{Ca}_{\mathrm{v}} 1.2^{\mathrm{cKO}}$ mice $(n=28)$ and control littermates $(n=39)$ over the course of $2 \mathrm{~d}$, in which mice received one unsignaled foot shock per day. The experimental protocol for these experiments is outlined in Figure
2A. Prior to delivery of the first footshock, mice in both groups exhibited negligible freezing, but as training progressed, the percentage of time spent freezing dramatically increased for both groups $\left(F_{(1,65)}=150.3 .2, P<0.0001\right.$; Fig. $\left.2 \mathrm{~B}\right)$; however, there was no difference between genotypes $\left(F_{(1,65)}=1.7, P>0.05\right.$; Fig. $\left.2 \mathrm{~B}\right)$ and no training-genotype interaction $\left(F_{(1,65)}=1.3, P>0.05\right.$; Fig. $2 \mathrm{~B})$, demonstrating that conditional deletion of $\mathrm{Ca}_{\mathrm{v}} 1.2$ does not significantly impact acquisition of contextually conditioned fear in mice. After training, mice were separated into four groups (control-retention [ $N=17]$, control-extinction $[N=22]$, $\mathrm{Ca}_{\mathrm{v}} 1.2^{\mathrm{cKO}}$-retention [ $\left.N=11\right], \mathrm{Ca}_{\mathrm{v}} 1.2^{\mathrm{CKO}}$-extinction [ $\left.N=17\right]$ ) based on similar day 2 post-shock freezing. On day 3 ( $24 \mathrm{~h}$ after the last day of training), mice in the extinction groups were returned to the fear conditioning chambers for a 3-min session. During this session, $\mathrm{Ca}_{\mathrm{v}} 1.2^{\mathrm{cKO}}$ and control mice froze similarly $\left(t_{(1,37)}=0.5, P>0.05\right.$; Fig. 2C). These data demonstrate that $\mathrm{Ca}_{\mathrm{v}} 1.2^{\mathrm{CKO}}$ mice are not impaired with respect to consolidation of contextually conditioned fear, and argue against a role for $\mathrm{Ca}_{\mathrm{v}} 1.2$ in consolidation of conditioned fear.

\section{$\mathrm{Ca}_{\mathrm{v}} 1.2^{\mathrm{cKO}}$ mice extinguish contextually conditioned fear as well as control mice}

Studies using antagonists for L-VGCCs have implicated a role for L-VGCCs in extinction of conditioned fear (Cain et al. 2002, 2005; Suzuki et al. 2004). Previously, we demonstrated that $\mathrm{Ca}_{\mathrm{v}} 1.3$ knockout $(\mathrm{KO})$ mice are able to extinguish contextually conditioned fear as well as wild-type mice (McKinney and Murphy 2006), suggesting that $\mathrm{Ca}_{\mathrm{v}} 1.3$ does not mediate extinction of contextually conditioned fear. Based on these data, we hypothesized that $\mathrm{Ca}_{\mathrm{v}} 1.2$ likely plays a role in the extinction of conditioned fear. To test this hypothesis, we exposed the mice that had been conditioned to extinction training by leaving them in the fear conditioning chambers for an additional $57 \mathrm{~min}$ after retention was assessed on day 3 (Fig. 2A). Short-term extinction was measured by assessing freezing for the first $30 \mathrm{~min}$ of this $1-\mathrm{h}$ extinction session. Both $\mathrm{Ca}_{\mathrm{v}} 1.2^{\mathrm{cKO}}(N=17)$ and control mice $(N=22)$ exhibited significant decreases in freezing across the first 30 min of training $\left(F_{(2,74)}=63.2, P<0.0001\right.$; Fig. 2D); however, there was no difference between genotypes $\left(F_{(1,37)}=0.4, P>0.05\right.$; Fig. 2D) and no training-genotype interaction $\left(F_{(2,74)}=0.08\right.$, $P>0.05$; Fig. 2D), demonstrating that conditional deletion of $\mathrm{Ca}_{\mathrm{v}} 1.2$ does not disrupt short-term, with-in session, extinction of contextually conditioned fear.

To explore the possibility that $\mathrm{Ca}_{\mathrm{v}} 1.2$ is involved in longterm, across-session, extinction of contextually conditioned fear, mice were returned to the conditioning chambers $24 \mathrm{~h}$ after extinction training (on day 4). In addition to the mice that were
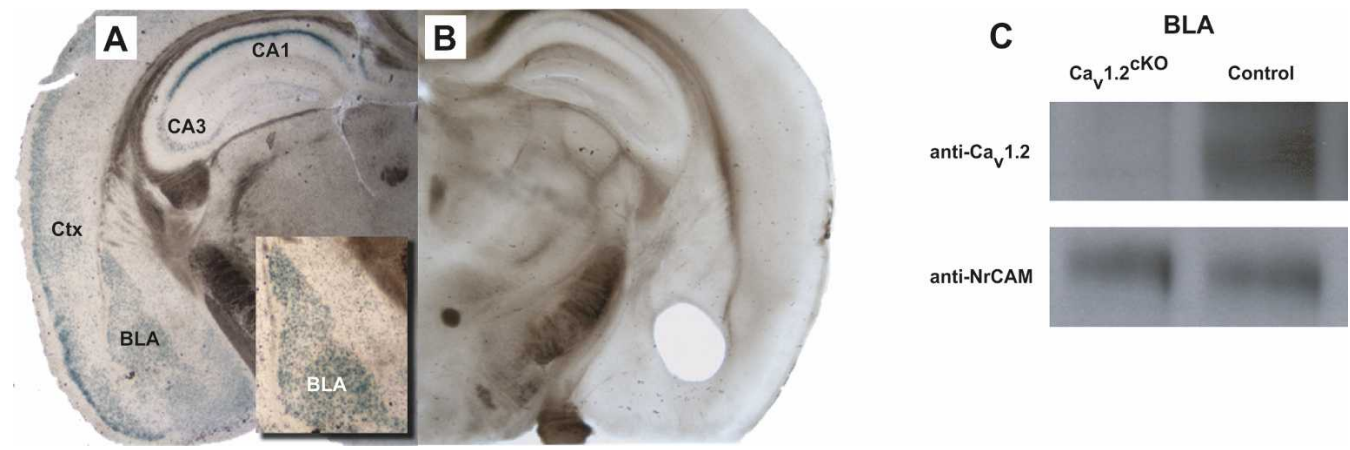

Figure 1. $\mathrm{Ca}_{\mathrm{v}} 1.2$ is deleted from the basolateral amygdala (BLA) of $\mathrm{Ca}_{v} 1.2^{\mathrm{cKO}}$ mice. (A) $\beta$-Galactosidase activity is detected in regions of the brain critical for consolidation and extinction of conditioned fear, including the cortex (Ctx), CA1 and CA3 regions of the hippocampus, and BLA of mice carrying both the CaMK-Cre and ROSA26 transgenes. (B) Representative brain section showing from where tissue was harvested for BLA immunoblotting (C) Immunoreactivity for $\mathrm{Ca}_{v} 1.2$ is present in $\mathrm{BLA}$ tissue from control, but not $\mathrm{Ca}_{\mathrm{v}} 1.2^{\mathrm{cKO}}$, mice. Similar immunoreactivity for the loading control (NrCAM) is present in BLA tissue from both $\mathrm{Ca}_{\mathrm{v}} 1.2^{\mathrm{cKO}}$ and control mice. 


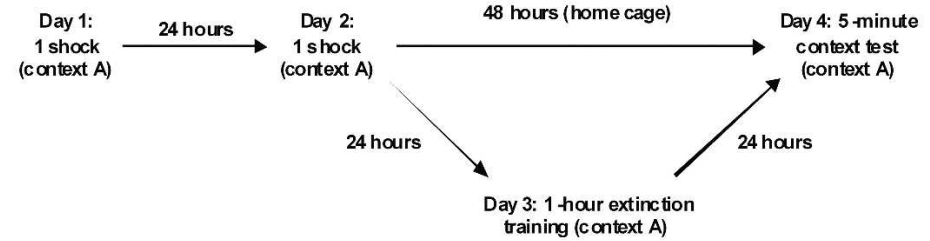

B

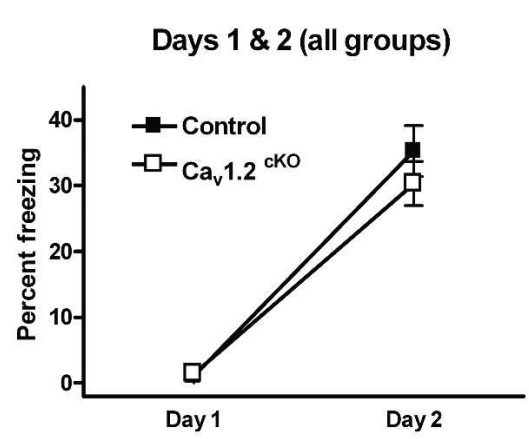

C

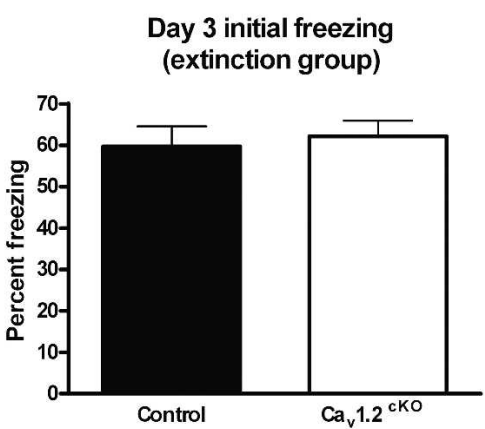

D

Day 3

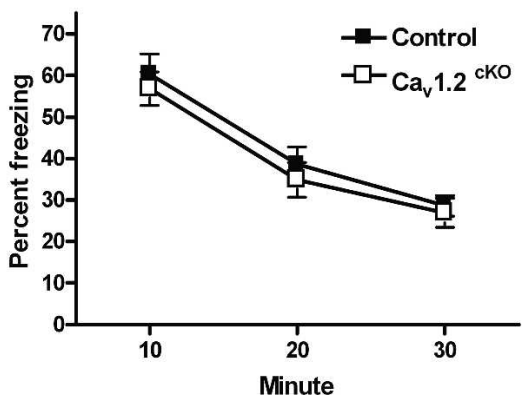

E

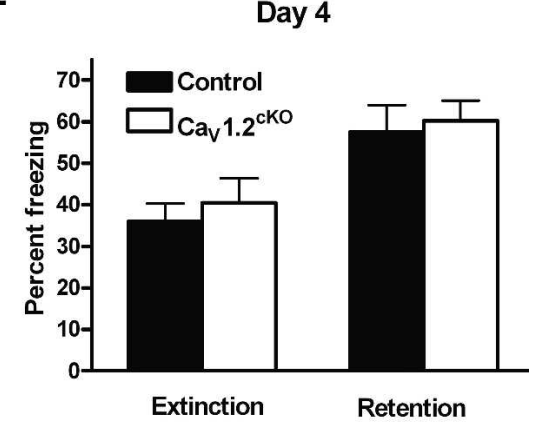

Figure 2. $\mathrm{Ca}_{\mathrm{v}} 1.2^{\mathrm{cKO}}$ mice consolidate and extinguish contextually conditioned fear as well as their control littermates. $(A)$ Training protocol, conditioning, and extinction training. (B) $\mathrm{Ca}_{\mathrm{v}} 1.2^{\mathrm{cKO}}$ and control mice exhibit similar levels of freezing prior to conditioning (day 1 ) and $24 \mathrm{~h}$ after the first conditioning trial (day 2). (C) $\mathrm{Ca}_{\mathrm{v}} 1.2^{\mathrm{cKO}}$ and control mice exhibit similar levels of freezing $24 \mathrm{~h}$ after the last conditioning trial. $(D) \mathrm{Ca}_{\mathrm{v}} 1.2^{\mathrm{cKO}}$ and control mice exhibit similar rates of extinction across the first 30 min of a 1-h extinction training session (day 3 ). (E) Twenty-four h after extinction training (day 4), mice were again exposed to the conditioning chambers, and both $\mathrm{Ca}_{\mathrm{v}} 1.2^{\mathrm{ckO}}$ mice and control mice exhibited significant reductions in freezing compared with mice of the same genotype that did not undergo extinction training (retention group). All data are presented as mean \pm SEM.

subjected to extinction training, a retention control group was also tested on day 4 . This group consisted of $\mathrm{Ca}_{\mathrm{v}} 1.2^{\text {cKO }}(N=10)$ and control mice $(N=17)$ that were conditioned identically as the group that received extinction training but were not subjected to extinction training themselves (Fig. 2A). When mice were returned to the conditioning chambers on day 4 to assess long-term retention of extinction, mice that were subjected to extinction training froze significantly less than those in the retention control group as revealed by a two-way ANOVA effect of training group (extinction training vs. retention control; $F_{(1,62)}=14.1, P<0.001$; Fig. 2E). However, there was no significant effect of genotype $\left(F_{(1,62)}=0.4, P>0.05\right.$; Fig. $\left.3 \mathrm{E}\right)$ or training group $\times$ genotype interaction $\left(F_{(1,62)}=0.03, P>0.05\right.$; Fig. $\left.3 \mathrm{E}\right)$ on day 4 freezing. From these experiments, we conclude that conditional deletion of $\mathrm{Ca}_{\mathrm{V}} 1.2$ does not disrupt long-term extinction of conditioned fear.
Taken collectively, the above data demonstrate conditional deletion of $\mathrm{Ca}_{\mathrm{v}} 1.2$ does not disrupt either shortterm or long-term extinction of contextually conditioned fear. Together with our previous work showing that $\mathrm{Ca}_{\mathrm{v}} 1.3$ $\mathrm{KO}$ mice are able to extinguish contextually conditioned fear as well as wildtype mice, these data argue against a role for L-VGCCs in the extinction of conditioned fear. This conclusion, however, is at odds with works using pharmacological antagonists for L-VGCCs that suggest a role for L-VGCCs in extinction of conditioned fear. As a first step toward addressing the discrepancy between results of extinction experiments performed using genetic mouse models and those that employed pharmacological antagonists, we tested our ability to block extinction of conditioned fear with the L-VGCC antagonist nifedipine using our protocol in wild-type mice with a similar genetic background as the $\mathrm{Ca}_{\mathrm{v}} 1.2^{\mathrm{cKO}}$ and $\mathrm{Ca}_{\mathrm{v}} 1.3$ $\mathrm{KO}$ mice used in our experiments.

\section{Consistent with previous reports, the L-VGCC antagonist nifedipine appears to block extinction of contextually conditioned fear}

The L-VGCCs antagonists nifedipine and nimodipine have been used previously to implicate L-VGCCs in the extinction of conditioned fear. Here, we sought to test our ability to reproduce the findings of Cain et al. (2002, 2005) using conditions similar to those used in our genetic studies of the extinction of conditioned fear. The experimental design is presented in Figure 3A. Like the mice in the above experiment, wild-type mice $(N=21)$ were conditioned once daily for $2 \mathrm{~d}$ with a single unsignaled footshock. Data from the first $2 \mathrm{~d}$ is presented in Figure 3B. Training resulted in a significant increase in freezing as measured on day $2\left(F_{(1,40)}=135 ; P<0.0001\right.$ for main effect of training).

Twenty-four hours after the last training trial (on day 3), mice were assigned to four matched treatment groups based on day 2 post-shock freezing. Two of the groups were returned to the conditioning chamber for $1 \mathrm{~h}$ of extinction training, and the other two groups were left in their home cages to serve as retention controls. Of the mice that were returned to the conditioning chambers for extinction training $(N=10)$, mice in one group $(N=6)$ were injected with nifedipine, and the mice in the other group $(N=4)$ were injected with saline 50 min before the beginning of extinction training. Similarly, of the two groups that were returned to their home cages to serve as retention controls, one group $(N=5)$ was injected with nifedipine, and mice in the other group $(N=6)$ were injected with saline $(N=6)$.

Injection of nifedipine before extinction training had no effect on initial levels of freezing as measured during the first 3 min of the extinction training $\left(t_{(8)}=0.126\right.$; Fig. 3C). However, 
A

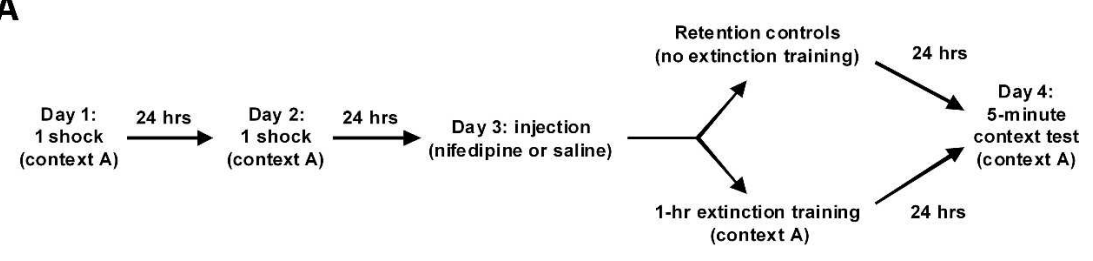

B

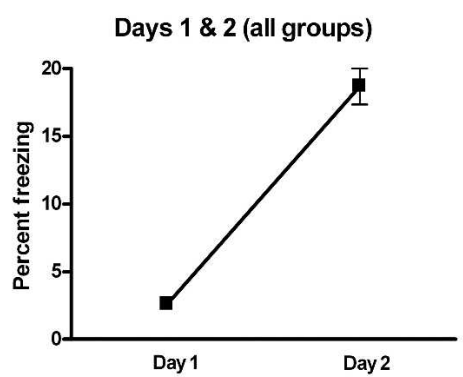

\section{C}

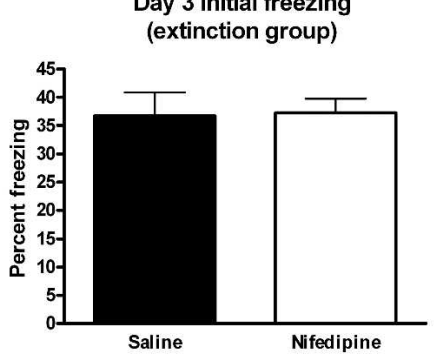

D

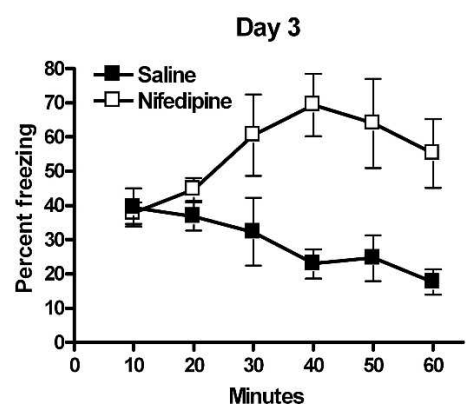

$\mathbf{E}$

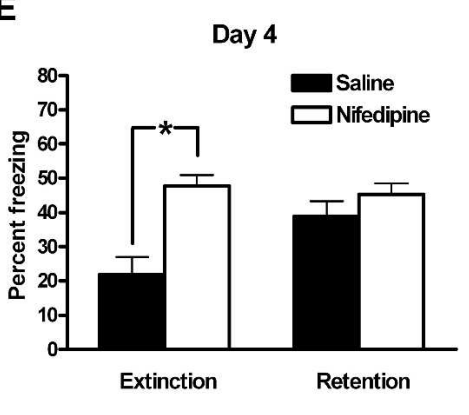

Figure 3. Consistent with previous reports, the L-VGCC antagonist nifedipine appears to block extinction of contextually conditioned fear. $(A)$ Training protocol, conditioning, and extinction training with nifedipine treatment. (B) Wild-type mice were conditioned with one shock daily for $2 \mathrm{~d}$ and exhibited significant freezing $24 \mathrm{~h}$ after the first conditioning trial. (C) Wild-type mice were separated into four groups based on day 2 post-shock freezing. Two of these groups were returned to the conditioning chambers $24 \mathrm{~h}$ after the second training trial and $50 \mathrm{~min}$ after treatment with nifedipine or saline. There was no difference in freezing between these two groups during the first 3 min of day 3. (D) Saline-treated mice exhibited significant reductions in freezing across a 1-h extinction training session (day 3); however, nifedipine-treated did not exhibit a similar reduction. (E) Twenty-four hours after extinction training (day 4), mice were again exposed to the conditioning chambers. Salinetreated mice exhibited significant reductions in freezing compared with similarly treated mice that did not undergo extinction training (retention group). Nifedipine-treated mice, however, exhibited similar levels of freezing as nifedipine-treated mice in the retention group. ${ }^{*} P<0.05$. All data are presented as mean \pm SEM.

mice that were injected with saline before extinction training exhibited a significant decrease in freezing as the extinction training proceeded, whereas those that were injected with nifedipine did not show a similar decrease in freezing (Fig. 3D). A repeated-measures ANOVA revealed that there was not a significant effect of extinction training on freezing across the session $\left(F_{(5,40)}=1.06, P>0.05\right.$; Fig. 3D), but that there was an effect of treatment $\left(F_{(1,40)}=7.36, P<0.05\right.$; Fig. $\left.3 \mathrm{D}\right)$ as well as an extinction training $\times$ treatment interaction $\left(F_{(5,40)}=7.87, P<0.0001\right.$; Fig. 3D), suggesting that nifedipine treatment blocks short-term, with-in session, extinction of contextually conditioned fear. Twenty-four hours following extinction training (day 4), all mice were returned to the conditioning chambers for a 5-min test session. A two-way ANOVA of freezing on day 4 revealed a significant effect of treatment (nifedipine vs. saline; $F_{(1,17)}=15.8$, $P<0.001$; Fig. 3E), but not training group (extinction training vs. retention control; $F_{(1,17)}=3.15, P>0.05$; Fig. 3E). However, there was a treatment $x$ training group interaction $\left(F_{(1,17)}=5.86\right.$,
$P<0.05$; Fig. 3E). Planned post-hoc comparisons (unpaired t-test) revealed that mice injected with saline and subjected to extinction training froze significantly less than retention control mice $\left(t_{(1,8)}=2.49, P<0.05\right.$; Fig. $\left.3 \mathrm{E}\right)$, but those that were injected with nifedipine and subjected to extinction training froze no less than retention control mice $\left(t_{(1,9)}=0.56, P<0.05\right.$; Fig. 3E), suggesting that nifedipine blocks long-term extinction of contextually conditioned fear. These results confirm previous reports that treatment with L-VGCC antagonists appears to block both shortterm and long-term extinction of conditioned fear.

While conducting these experiments it became apparent that mice injected with nifedipine were generally less active and more lethargic than mice injected with saline. It occurred to us that such an effect may complicate the use of nifedipine to study extinction and may lead to results that could be misinterpreted. To explore this possibility, we proceeded to examine the effect of nifedipine on locomotor activity and freezing behavior.

\section{Nifedipine decreases locomotor activity to an extent interpretable as freezing}

We first explored the effect of nifedipine on locomotor behavior using the openfield test. Mice were injected with nifedipine $(N=6)$ or saline $(N=6) 50 \mathrm{~min}$ prior to the open-field session. Mice were placed at the edge of the open field and allowed to explore for $5 \mathrm{~min}$; total distance traveled was measured. Nifedipine-treated mice traveled a significantly shorter distance $(1369.2 \pm 455.4 \mathrm{~cm})$ in the open field than saline-treated mice $\left(3091.3 \pm 427.78 ; t_{(1,10)}=2.76\right.$, $P<0.05)$, confirming our suspicion that nifedipine decreases locomotor activity.

We next explored if the decrease in locomotor activity induced by nifedipine could be misinterpreted as freezing. To do this, we repeated the conditioning and extinction protocol in the absence of footshocks (Fig. 4A). On days 1 and 2, mice were placed in the conditioning chambers for 4 min without shocking. On day 3 , mice were injected with either saline $(N=6)$ or nifedipine $(N=8)$ and returned to the conditioning chambers 50 min later for $1 \mathrm{~h}$ to simulate extinction training. On day 4 , mice were returned to the chamber for $5 \mathrm{~min}$. The saline- and nifedipine-treated mice both exhibited minimal freezing behavior on days 1 and 2 , and there was no difference between groups $\left(t_{(1,12)}=0.55\right.$ and 0.19 , respectively, $P>0.05$; data not shown). The nifedipine-treated group exhibited significant freezing on day 3. A two-way ANOVA revealed that there was a significant effect of treatment (saline vs. nifedipine; $F_{(1,72)}=204.6$, $P<0.0001$; Fig. 4B) and time-in-chamber $\left(F_{(5,72)}=6.67\right.$, $P<0.001$; Fig. 4B) on freezing as well as a treatmenttime-in-chamber interaction $\left(F_{(5,72)}=4.21, P<0.05\right.$; 
A.

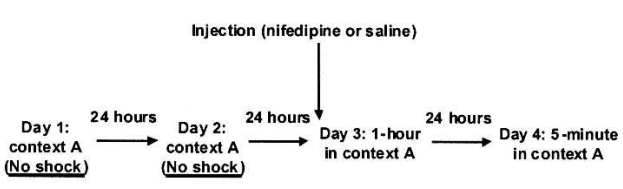

B.

Day 3

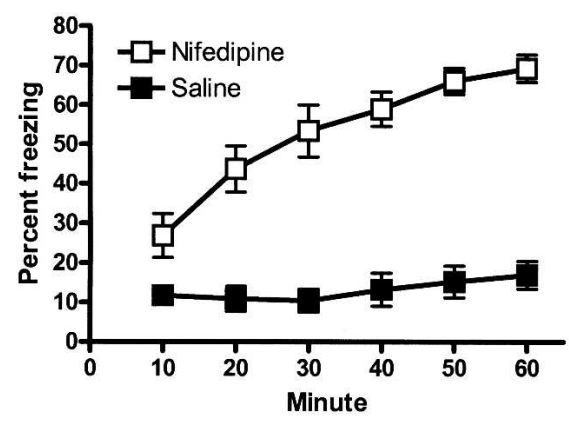

C.

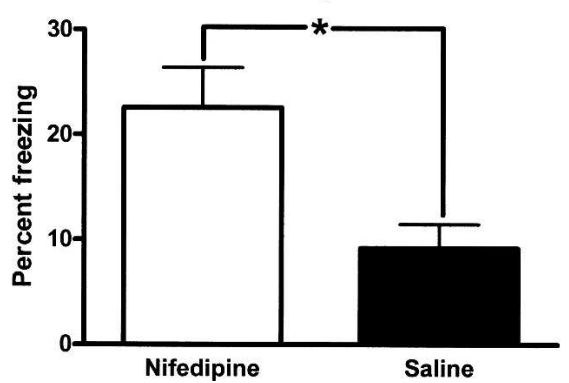

Figure 4. Nifedipine induces freezing that persists upon return to the conditioning chambers $24 \mathrm{~h}$ after treatment. (A) Training protocol, unconditioned freezing. $(B)$ Fifty minutes following treatment with nifedipine, mice freeze more than saline-treated mice when placed in the conditioning chambers for $1 \mathrm{~h}$. (C) Nifedipine-treated mice freeze more than saline-treated mice when returned to the conditioning chambers $24 \mathrm{~h}$ after treatment. ${ }^{*} P<0.05$. All data are presented as mean \pm SEM.

Fig. 4B). Nifedipine-treated mice exhibited more freezing during the day 3 session than saline-treated mice, suggesting that nifedipine treatment can affect locomotor activity to the extent that it can be measured as freezing and may explain why treatment with nifedipine appears to block short-term extinction of conditioned fear. However, the acute affect of nifedipine on locomotor activity and freezing behavior would not explain the previously demonstrated effect of nifedipine on blocking long-term extinction of conditioned fear. Interestingly, when mice were returned to the conditioning chambers and tested off-drug on day 4 , mice that had experienced the conditioning chambers under the influence of nifedipine on day 3 froze significantly more than those injected with saline before day 3 training $\left(t_{(1,12)}=2.77\right.$, $P<0.05$; Fig. 4C). These results suggest that treatment with nifedipine has long-term effects on freezing behavior. To us, these results resembled previous work suggesting that cues present during an aversive state can elicit species-specific defensive behaviors (e.g., freezing) upon subsequent presentation of the cues (McNally and Akil 2001).

\section{Long-term effect of nifedipine on freezing is context-specific}

If the long-term effect of nifedipine on freezing is the result of an association between the conditioning context and nifedipine- induced sickness, then the freezing observed when mice are tested $24 \mathrm{~h}$ after nifedipine treatment should be eliminated if testing is carried out in an alternate context, that is, in the absence of the CS. To explore if the long-term effects of nifedipine on freezing behavior are context-specific, we conducted an experiment similar to the one described immediately above with a minor modification-half of the mice were placed in the conditioning context during the long-term test (day 4) and the other half were placed in a reconfigured context during the long-term test (day 4) (Fig. 5A). As with the previous experiment, both the saline-treated mice $(N=16)$ and nifedipine-treated mice $(N=16)$ exhibited minimal freezing behavior on days 1 and 2 , and there was no difference between groups $\left(t_{(1,30)}=0.25\right.$ and 0.85 , respectively, $P>0.05$; data not shown). The nifedipine-treated group exhibited freezing on day 3. A two-way ANOVA revealed that there was a significant effect of treatment (saline vs. nifedipine; $F_{(1,180)}=99.3, P<0.0001 ;$ Fig. 5B) and time-in-chamber
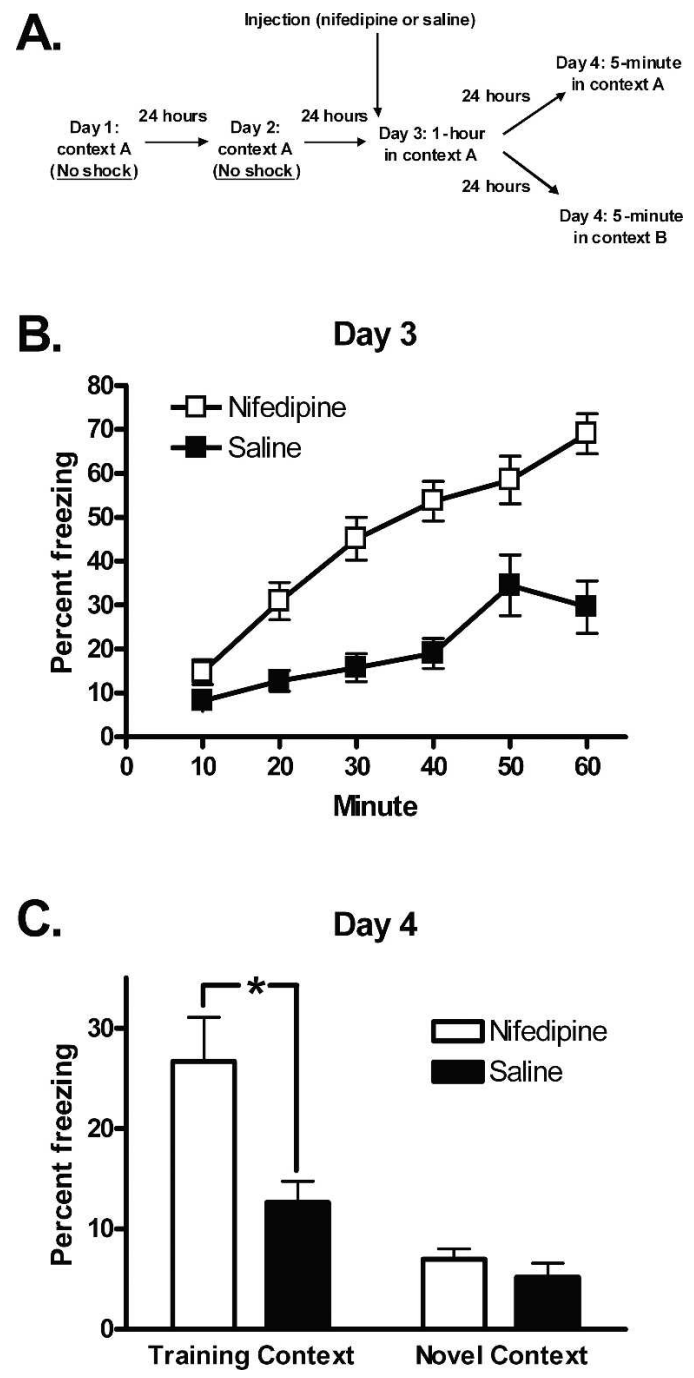

Figure 5. The long-term effect of nifedipine on freezing is contextspecific. (A) Training protocol. (B) Fifty minutes following treatment with nifedipine, mice freeze more than saline-treated mice when placed in the conditioning chambers for $1 \mathrm{~h}$. (C) Nifedipine-treated mice freeze more than saline-treated mice when returned to the conditioning chambers (training context) $24 \mathrm{~h}$ after treatment. When the conditioning chambers are reconfigured as a novel context, freezing does not differ between nifedipine- and saline-treated mice. ${ }^{*} P<0.05$. All data are presented as mean \pm SEM. 
$\left(F_{(5,180)}=21.7, P<0.001\right.$; Fig. $\left.5 \mathrm{~B}\right)$ on freezing as well as a treatment-time-in-chamber interaction $\left(F_{(5,180)}=3.65, P<0.05\right.$; Fig. $5 \mathrm{~B})$. On day 4 , approximately half of the mice returned to the same chamber in which they were placed on day 3 and the rest were placed in a reconfigured chamber, and freezing was measured for $5 \mathrm{~min}$. A two-way ANOVA revealed a significant effect of treatment $\left(F_{(1,28)}=9.48, P<0.01\right.$; Fig. 5C) and context $\left(F_{(1,28)}=27.8, P<0.0001\right.$; Fig. $\left.5 \mathrm{C}\right)$ on day 4 freezing as well as a treatment-context interaction $\left(F_{(1,28)}=0.73, P>0.05\right.$; Fig. $\left.5 \mathrm{C}\right)$. Planned post-hoc comparisons (unpaired t-test) reveal that nifedipine-treated mice freeze more than saline-treated mice when tested in the training context $\left(t_{(1,14)}=2.90, P<0.05\right.$; Fig. $\left.5 \mathrm{C}\right)$, but not in the reconfigured context $\left(t_{(1,14)}=1.05, P>0.05\right.$; Fig. $\left.5 \mathrm{C}\right)$. Mice exhibited less freezing in the novel environment than in the training context, independent of whether they were treated with nifedipine $\left(t_{(1,14)}=4.40, P<0.05\right.$; Fig. 5C) or saline $\left(t_{(1,14)}=2.97, P<0.05\right.$; Fig. $\left.5 \mathrm{C}\right)$, likely reflecting the phenomenon of novelty-induced exploration (van Abeelen 1989).

\section{Nifedipine-induced nausea associates with taste to produce conditioned taste avoidance}

In the conditioned taste avoidance (CTA) paradigm, mice learn to avoid drinking fluid with a specific taste after it has been paired with a nausea-inducing stimulus such as lithium chloride. To confirm that nifedipine was inducing an aversive state and could serve as an unconditioned stimulus and enter into an association with a cue, we paired saccharin with nifedipine $(N=6)$ or saline $(N=5)$ in wild-type mice and measured their avoidance of saccharin (avoidance index $=[(\mathrm{g}$ of water $) /(\mathrm{g}$ of water and saccharin) $] \times 100 \%) 24 \mathrm{~h}$ later. An unpaired t-test reveals that mice in which saccharin was paired with nifedipine avoided saccharin significantly more than mice in which saccharin was paired with saline (avoidance indices $=71.17 \pm 7.67$ and $48.77 \pm 5.25$, respectively; $t_{(1,9)}=2.37, P<0.05$; Fig. 6$)$. These data suggest that nifedipine can act as an unconditioned stimulus and thus supports our conclusion that the apparent blocking of long-term extinction of contextually conditioned fear by nifedipine is actually the elicitation of defensive freezing by the context in which extinction training was performed and thus illness experienced.

\section{Discussion}

In this study, we show that conditional deletion of $\mathrm{Ca}_{\mathrm{v}} 1.2$ does not significantly impact consolidation or extinction of contextually conditioned fear. Previously we have demonstrated that deletion of $\mathrm{Ca}_{\mathrm{v}} 1.3$, the alternate L-VGCC subtype, disrupts consolidation but not extinction of contextually conditioned fear. Taken collectively, these data suggest that L-VGCCs likely do not play a role in extinction of conditioned fear. However, consistent with previous reports by others and contradictory to our own genetic studies, we show that systemic treatment of wild-type mice with the L-VGCC antagonist nifedipine before extinction training appears to block both short-term and long-term extinction. However, upon further investigation, we found that the apparent ability of nifedipine to block extinction of conditioned fear does not reflect nifedipine's effect on extinction learning but instead is a product of nifedipine-induced aversive state. Specifically, we show that mice that are under the influence of nifedipine are less active than saline-treated mice, and in the fear conditioning chambers, this decreased activity can be interpreted as freezing behavior. Interestingly, mice that were treated with nifedipine and placed in the fear conditioning chambers continue to exhibit freezing when they are returned to the same fear conditioning chambers when they are tested off drug $24 \mathrm{~h}$ later. We have demonstrated that this "off-drug" freezing is context- dependent, which suggests that the long-term freezing in nifedipine-treated mice is the result of association being formed between the conditioning context and the nifedipine-induced aversive state. Further demonstrating that nifedipine can induce an aversive state and enter into an association with a cue, we show that nifedipine can be used as the unconditioned stimulus to induce conditioned avoidance of saccharin in a standard CTA paradigm.

Our conclusion that L-VGCCs likely do not play a role in extinction of conditioned fear appears to be at odds with previous studies. We suggest that this discrepancy is a result of the different approaches used: pharmacological versus genetic. In light of the data presented here regarding the apparent toxicity of nifedipine, it could be agued that if L-VGCCs do mediate extinction of conditioned fear, it is unlikely that their putative role could be uncovered with this approach.

We arrive at our conclusion that L-VGCCs likely do not play a role in extinction of conditioned fear by a process of elimination: Global deletion of $\mathrm{Ca}_{\mathrm{v}} 1.3$ disrupts consolidation but not extinction of contextually conditioned fear, while conditional deletion of $\mathrm{Ca}_{\mathrm{v}} 1.2$ does not disrupt either process. However we must consider at least four other alternate explanations that would still feature a role for L-VGCCs in the extinction of contextual fear conditioning.

The first explanation is that both brain-expressed L-VGCCs need to be blocked to realize impaired extinction of conditioned fear. Setting aside the toxicity issue discussed above for the moment-this would explain why treatment with L-VGCC antagonists and not genetic deletion of individual L-VGCC subtypes leads to impaired extinction of conditioned fear. Such an explanation would suggest that the two brain-expressed L-VGCCs $\left(\mathrm{Ca}_{\mathrm{v}} 1.2\right.$ and $\left.\mathrm{Ca}_{\mathrm{v}} 1.3\right)$ are functionally similar and one can compensate for the other in its absence. In our hands, however, there is no change in $\mathrm{Ca}_{\mathrm{v}} 1.3$ expression levels upon deletion of the gene for $\mathrm{Ca}_{\mathrm{v}} 1.2$ or vice versa (B.C. McKinney and G.G. Murphy, unpubl.). Further, $\mathrm{Ca}_{\mathrm{v}} 1.2$ and $\mathrm{Ca}_{\mathrm{v}} 1.3$ have quite different neuronal localization (Hell et al. 1993) and biophysical characteristics (Xu and Lipscombe 2001; Helton et al. 2005), making them unlikely functional substitutes for each other. Still, the possibility of a synergistic effect of simultaneous inactivation of both $\mathrm{Ca}_{\mathrm{v}} 1.2$ and $\mathrm{Ca}_{\mathrm{v}} 1.3$ cannot be dismissed.

The second explanation relates to the conditional nature of the deletion of $C a_{\mathrm{V}} 1.2$ in the present study. Because the gene for $\mathrm{Ca}_{\mathrm{v}} 1.2$ was deleted primarily in the forebrain of $\mathrm{Ca}_{\mathrm{v}} 1.2^{\mathrm{cKO}}$ mice, the lack of an effect on the ability to extinguish conditioned fear may have resulted from the gene for $\mathrm{Ca}_{\mathrm{v}} 1.2$ not being deleted in a critical region for extinction of conditioned fear. However, this seems unlikely given that $\mathrm{Ca}_{\mathrm{v}} 1.2$ in the $\mathrm{Ca}_{\mathrm{v}} 1.2^{\mathrm{cKO}}$ mice is deleted

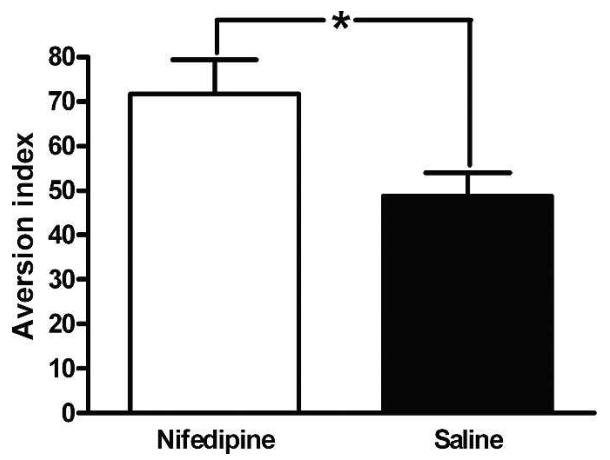

Figure 6. Nifedipine associates with taste to produce conditioned taste avoidance. Wild-type (WT) mice learn to avoid saccharin following a saccharin-nifedipine pairing. ${ }^{*} P<0.05$. All data are presented as mean \pm SEM. 
in most of the brain regions that are critical for extinction of conditioned fear, including the cortex, hippocampus (White et al. 2008), and the amygdala. This, of course, does not eliminate the possibility that $\mathrm{Ca}_{\mathrm{v}} 1.2$ is still expressed in a currently unrecognized area of the brain critical for extinction of conditioned fear.

Third, because the cre-recombinase expression in $\mathrm{Ca}_{\mathrm{v}} 1.2^{\mathrm{cKO}}$ mice was driven by the CaMKII $\alpha$ promoter, the gene for $\mathrm{Ca}_{\mathrm{v}} 1.2$ was only deleted in excitatory, but not inhibitory, neurons of the forebrain (Kelly 1991). If $\mathrm{Ca}_{\mathrm{v}} 1.2$ activity in inhibitory neurons is critical for the successful extinction of conditioned fear, then we would not have observed impaired extinction of conditioned fear in $\mathrm{Ca}_{\mathrm{v}} 1.2^{\mathrm{CKO}}$ mice as these mice presumably express the gene for $\mathrm{Ca}_{\mathrm{v}} 1.2$ in inhibitory neurons. If this were in fact the case, it would seem likely that $\mathrm{Ca}_{\mathrm{v}} 1.2$ is exerting its influence upon inhibitory neurons outside of the amygdala, since almost all of the $\mathrm{Ca}_{\mathrm{V}} 1.2$ immunoreactivity observed in the BLA is found in CaMKII $\alpha$-positive pyramidal neurons (Pinard et al. 2005).

And finally, the extinction protocol used here may not have been suitable for detecting $\mathrm{Ca}_{\mathrm{v}} 1.2$-mediated deficits in conditioned fear extinction. We demonstrated successful extinction of contextually conditioned fear using a single 1 -h context exposure. Though this protocol did not uncover an effect of genotype on extinction, it is possible that protocols that utilized longer exposure periods or different training styles (e.g., spaced extinction training) may have been more successful. We were, however, able to successfully reproduce the previously demonstrated effect of nifedipine on extinction using this protocol, and thus, it seems likely that this protocol would be sufficient to parse out any contribution of $\mathrm{Ca}_{\mathrm{v}} 1.2$ to the nifedipine effect. Our experiments, of course, do not rule out the contribution of $\mathrm{Ca}_{\mathrm{v}} 1.2$ to extinction in other paradigms (e.g., cue fear conditioning, Morris water maze).

Using a molecular genetics approach, we have begun to investigate the role that specific L-VGCCs isoforms play in Pavlovian fear conditioning. Based on the current study and our previous work and with the above alternate explanations withstanding, we conclude that $\mathrm{Ca}_{\mathrm{V}} 1.3$ plays a critical role in the consolidation of contextually conditioned fear and that LVGCCs do not mediate extinction of contextual conditioned fear memories.

\section{Materials and Methods}

\section{Mice}

Genetic studies were performed on mice in which the gene for the pore-forming subunit $\mathrm{Ca}_{\mathrm{v}} 1.2 \mathrm{~L}$-VGCC subtype was conditionally deleted in excitatory neurons of the mouse forebrain. To generate experimental mice, heterozygous floxed $\mathrm{Ca}_{\mathrm{V}} 1.2$ mice $\left(\mathrm{Ca}_{\mathrm{v}} 1.2^{\mathrm{f} /+}\right.$ mice $)$ that were maintained on a $129 \mathrm{SvEv}$ genetic background (White et al. 2008) were crossed with transgenic mice that expressed cre-recombinase under the control of the calcium calmodulin kinase II $\alpha$ (CaMKII $\alpha$ ) promoter (Chen et al. 2006). These mice (termed here as the CaMK-Cre mice), which express cre-recombinase in excitatory neurons of the forebrain (Chen et al. 2006), were propagated and maintained on a C57BL/ 6 NTac genetic background (10+ generations).

Offspring from the $\mathrm{Ca}_{\mathrm{V}} 1.2^{\mathrm{f} /+} \mathrm{X}$ CaMK-Cre ${ }^{\mathrm{Cre} /+}$ cross (the F1 generation) that were heterozygous floxed and Cre-positive (i.e., $\mathrm{Ca}_{\mathrm{V}} 1.2^{\mathrm{f} /+}$, CaMK-Cre $\mathrm{Cre} /+^{\mathrm{C}}$ ) were then intercrossed (nonsibling) to achieve the following genotypes: conditional knockout mice $\left(\mathrm{Ca}_{\mathrm{V}} 1.2^{\mathrm{f} / \mathrm{f}}\right.$, CaMK-Cre $\left.\mathrm{Cre} /+^{-}\right)$, wild-type mice $\left(\mathrm{Ca}_{\mathrm{V}} 1.2^{+/+}\right.$, CaMK$\left.\mathrm{Cre}^{+/+}\right)$, floxed controls $\left(\mathrm{Ca}_{\mathrm{V}} 1.2^{\mathrm{f} / \mathrm{f}}, \mathrm{CaMK}-\mathrm{Cre}^{+/+}\right)$, and Cre controls $\left(\mathrm{Ca}_{\mathrm{V}} 1.2^{+/+}, \mathrm{CaMK}-\mathrm{Cre} \mathrm{Cre} /+^{\mathrm{C}}\right)$ all on a $129 \mathrm{~S} 6 \mathrm{~B} 6 \mathrm{~F} 2 / \mathrm{Tac}$ hybrid genetic background. For ease of reading, conditional knockout mice $\left(\mathrm{Ca}_{\mathrm{V}} 1.2^{\mathrm{f} / \mathrm{f}}, \mathrm{CaMK}-\mathrm{Cre} \mathrm{Cre} /+^{\mathrm{C}}\right)$ are referred to as $\mathrm{Ca}_{\mathrm{V}} 1.2^{\mathrm{cKO}}$ throughout the text. For the fear conditioning experiments, all four genotypes were used. A post-hoc repeated-measures ANOVA of the three control genotypes $\left(\mathrm{Ca}_{\mathrm{V}} 1.2^{+/+}, \mathrm{CaMK}_{-} \mathrm{Cre}^{+/+}\right.$; $\mathrm{Ca}_{\mathrm{V}} 1.2^{\mathrm{f} / \mathrm{f}}, \mathrm{CaMK}_{-\mathrm{Cre}}{ }^{+/} ;$and $\mathrm{Ca}_{\mathrm{V}} 1.2^{+/+}$, CaMK-Cre ${ }^{\mathrm{Cre} /+}$ ) revealed no significant difference in freezing during training $\left(F_{(2,36)}=2.6\right.$; $P>0.05$, for the effect of genotype) or during extinction training $\left(F_{(2,19)}=2.6 ; P>0.05\right.$, for the effect of genotype $)$, therefore the three genotypes are presented in aggregate (labeled as "controls").

All pharmacological studies were done on wild-type mice with a 129S6B6F2/Tac hybrid genetic background. To obtain these mice, 129S6B6F1/Tac hybrid mice were generated first by crossing C57BL/6NTac mice purchased from Taconic Farms with 129S6/SvEvTac mice that were similarly obtained. 129S6B6F1/ Tac mice were subsequently intercrossed to obtain experimental mice.

Mice were housed under uniform conditions including a 12-h/12-h light/dark cycle with lights on at $0600 \mathrm{~h}$, average temperature of $22^{\circ} \mathrm{C}$, and ad libitum food and water. Mice were housed together in groups of three to five with same-sex siblings. Mice were between 2 and 6 mo of age at testing, and approximately equal numbers of male and female mice were used in all experiments. Behaviorally naïve mice were used in each experiment. All experiments were conducted according to National Institutes of Health guidelines for animal care and were approved by the University Committee on Use and Care of Animals of the University of Michigan.

\section{X-gal staining}

Cre expression in CaMK-Cre mice was localized with the aid of R26R reporter mice that carry the loxP-STOP-loxP-lacZ cassette targeted into the ubiquitously expressed ROSA26 locus (Soriano 1999), a generous gift from Dr. Miriam Meisler (Dept. of Human Genetics, University of Michigan, Ann Arbor).

Brain sections from mice carrying both the CaMK-Cre and loxP-STOP-loxP-lacZ transgenes were stained for $\beta$-galactosidase activity. Mice were anesthetized and decapitated, and their brains were removed and immediately frozen in isopentane $\left(-30^{\circ} \mathrm{C}\right)$. Brains were then sectioned $(40 \mu \mathrm{m})$, mounted on microscope slides, and stained overnight at $37^{\circ} \mathrm{C}$ with X-gal staining solution $\left(1 \mathrm{mg} / \mathrm{mL} \mathrm{X-gal,} 50 \mathrm{mM} \mathrm{K}{ }_{4} \mathrm{Fe}(\mathrm{CN})_{6}, 5 \mathrm{mM}\right.$ $\mathrm{K}_{3} \mathrm{Fe}(\mathrm{CN})_{6}, 2 \mathrm{mM} \mathrm{MgCl}{ }_{2}$ in $100 \mathrm{mM}$ phosphate buffer at $\left.\mathrm{pH} 7.5\right)$. After staining, sections were washed with PBS, fixed in $4 \%$ paraformaldehyde, cover-slipped, and imaged.

\section{Immunoblotting}

Immunoblotting was carried out as previously described (White et al. 2008) using BLA samples from $\mathrm{Ca}_{\mathrm{v}} 1.2^{\mathrm{cKO}}$ mice and control $\left(\mathrm{Ca}_{\mathrm{V}} 1.2^{+/+}, \mathrm{CaMK}_{-} \mathrm{Cre}^{+/+}\right)$littermates. Mice were anesthetized and decapitated, and their brains were removed and placed in HSE buffer (10 mM HEPES, $350 \mathrm{mM}$ sucrose, $5 \mathrm{mM}$ EDTA at $\mathrm{pH} 7.4$ ) containing Complete Protease Inhibitor (Roche Diagnostics). Brains were then sectioned and the BLA removed with a $0.5-\mathrm{mm}$ diameter sample corer (Fine Science Tools). The BLA samples were then homogenized and the homogenate centrifuged for 5 min at $2000 \mathrm{~g}$ at $4^{\circ} \mathrm{C}$. The supernatant was removed, and protein content was determined by Bradford assay (Bio-Rad), using bovine serum albumin (BSA) as a standard. BLA protein samples (50 $\mu \mathrm{g}$ ) were solubilized in Laemelli buffer separated on a $7.5 \%$ SDSPAGE gel and transferred to PVDF membranes (Bio-Rad) overnight. Blots were probed with an anti-Ca ${ }_{\mathrm{V}} 1.2$ antibody (1:200; Alomone Labs product no. ACC-022, lot no. AN-03) whose epitope is located in the $\mathrm{N}$ terminus of the protein (residues two to $15)$. Blots were also probed with an NrCAM-specific antibody (1:40000; ABCAM), which served as the loading control. Incubation with the primary antibody was followed by washing with PBS-Tween and incubation with a horseradish peroxidaseconjugated anti-rabbit secondary (Bio-Rad, 1:5000). Blots were washed, and immunoreactivity was visualized with an enhanced chemiluminescence detection system (ECL Plus, Amersham).

\section{Drug}

The LVGCC antagonist nifedipine (40 mg/kg; Sigma) was sonicated into $100 \%$ Cremophor (Sigma). Saline was added to make 
the final vehicle $10 \%$ Cremophor/90\% saline. This dose of nifedipine was a partial suspension, and thus, care was taken to thoroughly mix prior to injecting. Mice were injected $50 \mathrm{~min}$ prior to behavioral testing $(10 \mathrm{~mL} / \mathrm{kg})$ in all experiments. Drug dose and pretreatment time were based on previous studies of nifedipine and conditioned fear (Cain et al. 2002, 2005).

\section{Pavlovian fear conditioning}

\section{Conditioning apparatus}

Pavlovian fear conditioning was performed as previously described (McKinney and Murphy 2006; McKinney et al. 2008). Each of the four conditioning chambers was equipped with a stainless steel grid floor designed for mice (Med Associates). The grid floor was positioned over a stainless steel drop-pan, which was lightly cleaned with $95 \%$ ethyl alcohol to provide a background odor. The front, top, and back of the chamber were made of clear acrylic, and the two sides were made of modular aluminum. The conditioning chambers were arranged in a two-by-two configuration on a steel rack. The rack was positioned in an isolated room lit by overhead fluorescent lighting. Each chamber was connected to a solid-state shock scrambler, and each scrambler was connected to an electronic constant-current shock source that was controlled via an interface connected to a Dell Windows XP computer running Actimetrics FreezeFrame software (Actimetrics). Four cameras were mounted (one above each chamber) to the steel rack, and video signals were sent to the same computer. Freezing was defined as the absence of movement except that associated with respiration and was measured by subjecting the video signal to a sensitive global motiondetection algorithm (Freezeframe and Freezeview software; Actimetrics).

\section{Contextual fear conditioning}

Mice received two training trials (one trial per day) in a 3-min stimulus-free interval followed by a 2 -sec, $0.50-\mathrm{mA}$ footshock delivered via the grid floor. Fifty-eight seconds after the footshock, mice were removed from the chambers and returned to their home cages. Twenty-four hours after the second day of training, mice were returned to the fear conditioning chambers for a 3 -min retention test.

\section{Extinction of contextually conditioned fear}

Mice that received extinction training were first conditioned as described above. Twenty-four hours after the second conditioning trial (on day 3), mice were returned to the same chambers and extinction training commenced. Extinction training consisted of a single 1-h exposure to the training context in the absence of footshock. Retention controls were included in extinction experiments. These mice were treated identically to those that received extinction training except that they were not subjected to the 1-h extinction session. On the following day, all mice were returned to the same chambers for a 5-min test session.

\section{Open field}

Locomotor activity was assessed in an open field as described by McKinney and Murphy (2006) and McKinney et al. (2008). On day 1 of open-field testing, mice were injected with nifedipine or saline $50 \mathrm{~min}$ before being placed in the open field. Mice were placed at the edge of the open field and allowed to explore for 5 min. Distance traveled was measured using Actimetrics software.

\section{Unconditioned freezing behavior in fear conditioning chambers}

Mice were placed in the fear conditioning chambers for $4 \mathrm{~min}$ a day for 2 d. On day 3 , mice were injected with nifedipine or saline $50 \mathrm{~min}$ before being returned to the fear conditioning chambers for $1 \mathrm{~h}$. On day 4 , mice were returned to the same fear conditioning chambers or reconfigured fear conditioning chambers for $5 \mathrm{~min}$. This protocol was designed to be identical to the fear conditioning/extinction protocol described above except that no shocks were delivered and the fear conditioning chambers were reconfigured in a subset of experiments. Freezing was measured on all $4 \mathrm{~d}$. Freezing was defined as the absence of movement except that associated with respiration and was measured by subjecting the video signal to a sensitive global motiondetection algorithm (Freezeframe and Freezeview software; Actimetrics).

\section{Conditioned taste avoidance}

CTA was performed using the method of Josselyn et al. (2004). Mice were singly-housed in cages with food but no water $20 \mathrm{~h}$ before the experiment. During a 5-d habituation period, mice were given access to two drinking bottles filled with water for decreasing periods of time each day $(4 \mathrm{~h}, 2 \mathrm{~h}, 1 \mathrm{~h}, 30 \mathrm{~min}, 30 \mathrm{~min}$ drinking period). On day 6 , mice were presented with a single bottle filled with $2 \mathrm{mM}$ saccharin for $30 \mathrm{~min}$. Thirty minutes after the drinking session, mice were injected with $40 \mathrm{mg} / \mathrm{kg}$ nifedipine or $0.15 \mathrm{M} \mathrm{LiCl}$ at a dose of $2 \%$ body weight. Twenty-four hours later, mice were given a choice test in which they were presented with two bottles for $30 \mathrm{~min}$; one containing $2 \mathrm{mM}$ saccharin and the other containing water. Liquid consumed from each bottle was measured, and an aversion index (AI) was calculated as follows: [ $(\mathrm{g}$ of water)/(g of water and saccharin) $] \times 100 \%$.

\section{Statistical analysis}

All data are presented as mean \pm SEM. Fear conditioning acquisition/consolidation and extinction training data were analyzed using repeated-measures ANOVA with a between-subject factor for genotype or treatment group and a repeated-measure for training day or time-in-chamber. Unpaired $t$-tests between genotypes were used to analyze data from the final test session of acquisition/consolidation training. Two-way ANOVAs with genotype or treatment group and training group (extinction vs. retention) or testing context (training vs. novel) were used to analyze data from the long-term extinction test sessions. Unpaired t-tests were used for post-hoc comparisons when there was a significant interaction between factors. Open field and CTA data were analyzed using unpaired t-tests between treatment or pairing groups, respectively. Results were considered significantly different when $P<0.05$.

\section{References}

Bauer, E.P., Schafe, G.E., and LeDoux, J.E. 2002. NMDA receptors and L-type voltage-gated calcium channels contribute to long-term potentiation and different components of fear memory formation in the lateral amygdala. J. Neurosci. 22: 5239-5249.

Cain, C.K., Blouin, A.M., and Barad, M. 2002. L-type voltage-gated calcium channels are required for extinction, but not for acquisition or expression, of conditional fear in mice. J. Neurosci. 22: 9113-9121.

Cain, C.K., Godsil, B.P., Jami, S., and Barad, M. 2005. The L-type calcium channel blocker nifedipine impairs extinction, but not reduced contingency effects, in mice. Learn. Mem. 12: 277-284.

Chen, A.P., Ohno, M., Giese, K.P., Kühn, R., Chen, R.L., and Silva, A.J. 2006. Forebrain-specific knockout of B-raf kinase leads to deficits in hippocampal long-term potentiation, learning, and memory. $J$. Neurosci. Res. 83: 28-38.

Delgado, M.R., Olsson, A., and Phelps, E.A. 2006. Extending animal models of fear conditioning to humans. Biol. Psychol. 73: 39-48.

Fanselow, M.S. and Poulos, A.M. 2005. The neuroscience of mammalian associative learning. Annu. Rev. Psychol. 56: 207-234.

Hell, J., Westenbroek, R., Warner, C., Ahlijanian, M., Prystay, W., Gilbert, M., Snutch, T., and Catterall, W. 1993. Identification and differential subcellular localization of the neuronal class $C$ and class D L-type calcium channel $\alpha 1$ subunits. J. Cell Biol. 123: 949-962.

Helton, T.D., Xu, W., and Lipscombe, D. 2005. Neuronal L-type calcium channels open quickly and are inhibited slowly. J. Neurosci. 25: $10247-10251$.

Hofmann, S.G. 2007. Cognitive processes during fear acquisition and extinction in animals and humans: Implications for exposure therapy of anxiety disorders. Clin. Psychol. Rev. 28: 200-211.

Josselyn, S.A., Kida, S., and Silva, A.J. 2004. Inducible repression of CREB function disrupts amygdala-dependent memory. Neurobiol. Learn. Mem. 82: 159-163. 
Kelly, P.T. 1991. Calmodulin-dependent protein kinase II. Multifunctional roles in neuronal differentiation and synaptic plasticity. Mol. Neurobiol. 5: 153-177.

Maren, S. 2001. Neurobiology of Pavlovian fear conditioning. Annu. Rev. Neurosci. 24: 897-931.

McKinney, B.C. and Murphy, G.G. 2006. The L-type voltage-gated calcium channel $\mathrm{Ca}_{\mathrm{V}} 1.3$ mediates consolidation, but not extinction, of contextually conditioned fear in mice. Learn. Mem. 13: 584-589.

McKinney, B.C., Schneider, J.S., Schafer, G.L., Lowing, J.L., Mohan, S., Zhao, M.X., Heng, M.Y., Albin, R.L., Seasholtz, A.F., Akil, H., et al. 2008. Decreased locomotor activity in mice expressing tTA under control of the CaMKII $\alpha$ promoter. Genes Brain Behav. 7: 203-213.

McNally, G. and Akil, H. 2001. Effects of contextual or olfactory cues previously paired with morphine withdrawal on behavior and pain sensitivity in the rat. Psychopharmacology 156: 381-387.

Myers, K.M. and Davis, M. 2006. Mechanisms of fear extinction. Mol. Psychiatry 12: 120-150.

Pinard, C.R., Mascagni, F., and McDonald, A.J. 2005. Neuronal localization of $\mathrm{Ca}_{\mathrm{V}} 1.2 \mathrm{~L}$-type calcium channels in the rat basolateral amygdala. Brain Res. 1064: 52-55.
Soriano, P. 1999. Generalized lacZ expression with the ROSA26 Cre reporter strain. Nat. Genet. 21: $70-71$.

Suzuki, A., Josselyn, S.A., Frankland, P.W., Masushige, S., Silva, A.J., and Kida, S. 2004. Memory reconsolidation and extinction have distinct temporal and biochemical signatures. J. Neurosci. 24: 4787-4795.

van Abeelen, J.H. 1989. Genetic control of hippocampal cholinergic and dynorphinergic mechanisms regulating novelty-induced exploratory behavior in house mice. Experientia 45: 839-845.

White, J.A., McKinney, B.C., John, M.C., Powers, P.A., Kamp, T.J., and Murphy, G.G. 2008. Conditional forebrain deletion of the L-type calcium channel $\mathrm{Ca}_{\mathrm{v}} 1.2$ disrupts remote spatial memories in mice. Learn. Mem. 15: 1-5.

$\mathrm{Xu}, \mathrm{W}$. and Lipscombe, D. 2001. Neuronal $\mathrm{Ca}_{\mathrm{V}} 1.3 \alpha_{1}$ L-type channels activate at relatively hyperpolarized membrane potentials and are incompletely inhibited by dihydropyridines. J. Neurosci. 21: 5944-5951.

Received December 21, 2007; accepted in revised form February 11, 2008. 


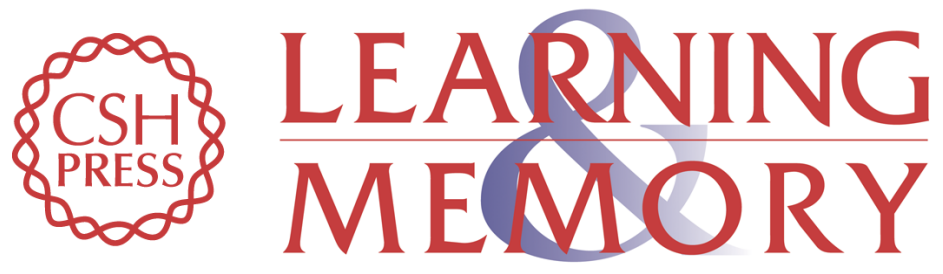

\section{L-type voltage-gated calcium channels in conditioned fear: A genetic and pharmacological analysis}

Brandon C. McKinney, Wilson Sze, Jessica A. White, et al.

Learn. Mem. 2008, 15:

Access the most recent version at doi:10.1101//m.893808

References This article cites 22 articles, 9 of which can be accessed free at:

http://learnmem.cshlp.org/content/15/5/326.full.html\#ref-list-1

License

Email Alerting Receive free email alerts when new articles cite this article - sign up in the box at the Service top right corner of the article or click here. 